\title{
Phytophthora palmivora: agente causal da podridão da base do estipe da pupunheira no Brasil
}

\author{
Heloíse Volpe Lopes ${ }^{1} \oplus$, Álvaro Figueredo dos Santos ${ }^{2,5} \oplus$, \\ Edna Dora Martins Newman Luz ${ }^{3,5}$, Dauri José Tessmann ${ }^{4,5}$
}

${ }^{1}$ Programa de Pós-Graduação em Agronomia, Universidade Federal do Paraná, rua dos Funcionários, 1540, Cabral, CEP 80.035-050, Curitiba -PR, Brasil; ${ }^{2}$ Embrapa Florestas, Estrada da Ribeira, Km 111, CEP 83.411-000, Colombo - PR, Brasil; ${ }^{3}$ MAPA/CEPEC/CEPLAC, Rodovia Ilhéus/ Itabuna, Km 22, CEP 45.600-970, Ilhéus-BA, Brasil; ${ }^{4}$ Universidade Estadual de Maringá, Av. Colombo, 5790, CEP 87.020-900, Maringá - PR, Brasil; ${ }^{5}$ Bolsista CNPq.

Autor para correspondência: Álvaro Figueredo dos Santos (alvaro.santos@embrapa.br)

Data de chegada: 01/04/2018. Aceito para publicação em: 05/02/2019.

$10.1590 / 0100-5405 / 189782$

\section{RESUMO}

Lopes, H.V.; Santos, A.F.; Luz, E.D.M.N.; Tessmann, D.J. Phytophthora palmivora: agente causal da podridão da base do estipe da pupunheira no Brasil. Summa Phytopathologica, v.45, n.2, p.164-171, 2019.

A área plantada com pupunheira (Bactris gasipaes) para a produção de palmito tem aumentado nos estados da Bahia, Espírito Santo, Rio de Janeiro, Tocantins, São Paulo, Paraná e Santa Catarina. Nestas regiões os plantios são atacados pela podridão da base do estipe (PBE), associada ao oomiceto Phytophthora palmivora. Há poucos trabalhos sobre a etiologia desta doença, pairando e, as vezes, ficam dúvidas sobre a espécie de Phytophthora envolvida. Desta forma, o objetivo deste trabalho foi identificar e caracterizar morfológica, fisiológica e molecularmente, os isolados de Phytophthora sp. oriundos de três polos de plantios de pupunheira, visando elucidar a sua etiologia. Os 31 isolados de Phytophthora utilizados vieram de plantios de pupunheira dos estados de São Paulo (Eldorado, Cajati e Registro), Paraná (Paranaguá e Morretes) e Santa Catarina (Massaranduba, Garuva e Joinville). Avaliou-se o crescimento micelial dos isolados de Phytophthora sp. em oito temperaturas (8, 12, 16, 20, 24, 28 , 32 e $36^{\circ} \mathrm{C}$ ), o aspecto das colônias, a produção de esporângios, clamidósporos e oósporos. Foram medidas 50 estruturas de cada isolado e a análise molecular com base nas regiões ITS1 e ITS2 e $\operatorname{Cox} 1$ e $\operatorname{Cox} 2$. Os três padrões de colônia encontrados foram: ligeiramente estrelado, estrelado e cotonoso, sendo o primeiro o mais frequente. Os isolados não cresceram às temperaturas de 8 ${ }^{\circ} \mathrm{C}$ e $36^{\circ} \mathrm{C}$, e a temperatura ótima foi $23,7^{\circ} \mathrm{C}$. Os esporângios formados em ontogenia simpodial apresentaram-se papilados, elipsoides em sua maioria, com 21,1 - 84,8 $\mu \mathrm{m}$ de comprimento e 17,4-41,7 $\mu \mathrm{m}$ de largura, caducos, com pedicelos curtos $0,4-6,6 \mu \mathrm{m}$, e relação comprimento/largura $(\mathrm{C} / \mathrm{L})$ variando de 1,3 - 1,9. As papilas mediram entre 0,9 - 11,2 $\mu \mathrm{m}$ de profundidade e 0,5 - 11,4 $\mu \mathrm{m}$ de largura. Clamidósporos globosos, terminais e intercalares, com 20,0 $53,6 \mu \mathrm{m}$ de diâmetro e $0,3-4,4 \mu \mathrm{m}$ de espessura de parede. Todos os isolados foram heterotálicos e do tipo compatível A1. Oósporos globosos, apleróticos e sem ornamentações nas paredes medindo 26,0 - 63,6 $\mu \mathrm{m}$, com anterídios anfígenos. Com base nas características morfofisiológicas e moleculares, os isolados de pupunheira foram enquadrados na espécie Phytophthora palmivora (Butler) Butler.

Palavras-chave: taxonomia, oomiceto, Bactris gasipaes

\section{ABSTRACT}

Lopes, H.V.; Santos, A.F.; Luz, E.D.M.N.; Tessmann, D.J. Phytophthora palmivora: causal agent of peach palm stem base rot in Brazil. Summa Phytopathologica, v.45, n.2, p.164-171, 2019.

The area planted with peach palm (Bactris gasipaes) for the production of palm heart has increased in the Brazilian states of Bahia, Espírito Santo, Rio de Janeiro, Tocantins, São Paulo, Paraná and Santa Catarina. In these regions, the crops are attacked by stipe basal rot (SBR), a disease associated with the oomycete Phytophthora palmivora. There are few studies on this disease, and some doubts about the species Phytophthora palmivora remain. Thus, the objective of this study was to identify and morphologically, physiologically and molecularly characterize Phytophthora sp. isolates obtained from three peach palm plantation sites in order to elucidate its etiology. The 31 Phytophthora isolates were obtained from peach palm crops in the states of São Paulo (Eldorado, Cajati and Registro), Paraná (Paranaguá and Morretes) and Santa Catarina (Massaranduba, Garuva and Joinville). Mycelial growth of isolates was evaluated at eight temperatures $(8,12$, $16,20,24,28,32$ and $36^{\circ} \mathrm{C}$ ), as well as the aspect of the colony and the production of sporangia, chlamydospores and oospores. Fifty structures

Keywords: taxonomy, oomycete, Bactris gasipaes

A pupunheira (Bactris gasipaes Kunth. var. gasipaes Henderson) é uma espécie florestal nativa da Amazônia brasileira que tem sido plantada para produção de palmito em várias regiões brasileiras, como of each isolate were measured, as well as molecular analysis based on the regions ITS 1 and ITS2 and Cox 1 and Cox 2 . Three colony patterns were found: slightly starry, starry and cottony, and the first pattern was most frequent. There was no growth at $8{ }^{\circ} \mathrm{C}$ and $36^{\circ} \mathrm{C}$ and the optimal growth temperature was $23.7^{\circ} \mathrm{C}$. The sporangia formed on sympodial ontogeny were papillate, predominantly ellipsoid, showing $21.1-84.8 \mu \mathrm{m}$ length and $17.4-41.7 \mu \mathrm{m}$ width, caducous, with a short pedicel of $0.4-6.6 \mu \mathrm{m}$ and a length-to-width ratio varying from 1.3 to 1.9 . The papillae measured between $0.9-11.2 \mu \mathrm{m}$ length and $0.5-11.4 \mu \mathrm{m}$ width. Chlamydospores were globose, terminal and interpolate, showing 20.0 - 53.6 $\mu \mathrm{m}$ diameter and $0.3-4.4 \mu \mathrm{m}$ wall thickness. All isolates were heterothalic of the compatible mating type A1. Oospores were globose and aplerotic with no ornamented walls, measuring $26.0-63.6 \mu \mathrm{m}$, and showing amphigynous antheridia. Based on these morphological and molecular characteristics, the peach palm isolates were identified as Phytophthora palmivora (Butler) Butler.

nos estados da Bahia, Espírito Santo, Rio de Janeiro, São Paulo e, mais recentemente no Sul, nos estados do Paraná e Santa Catarina (14), atingindo 20.000 ha em 2014 e uma produção aproximada de 116 mil 
toneladas (15). A pupunheira é uma boa opção para os produtores rurais, pois permite cortes sucessivos de palmito por vários anos, perfilha, tem ciclo precoce e o palmito não oxida após o corte, o que permite a sua comercialização in natura (19). Além disso, a pupunheira tem grande importância ecológica, por diminuir a pressão de consumo do palmito juçara (Euterpe edulis Martius), planta que é explorada de forma extrativista na Mata Atlântica, com riscos de extinção pela redução de suas populações naturais (19).

Com a expansão da área plantada com pupunheira incentivaram-se os problemas fitossanitários em viveiros e plantios (19) destacando-se a doença podridão da base do estipe (PBE). As plantas com sintomas da PBE caracterizam-se pela murcha e amarelecimento da folha bandeira (folha não aberta), seguido do amarelecimento e seca das demais folhas, podendo provocar a morte da planta-mãe e, às vezes, dos perfilhos e de toda a touceira $(2,18)$. O que chama a atenção na fase inicial desta doença é o amarelecimento da folha bandeira, a qual pode ser arrancada facilmente do caule. Em plantios comerciais de Goiás constatou-se a incidência de até $50 \%$ de indivíduos atacados (27) e, em viveiro da Bahia, Santos \& Luz (24) relataram perdas de até $70 \%$ de plantas com a PBE. No estado do Pará, Benchimol et al. (2) registraram perdas de $30 \%$ em mudas enviveiradas e $10 \%$ em plantas adultas. Em outras regiões, como São Paulo, Santa Catarina e Paraná, tem-se verificado o aumento nos últimos anos da ocorrência desta doença $(8,10)$. A PBE causa a morte da touceira e, por poder ser a pupunheira explorada por mais de 15 anos, permitindo cortes periódicos de seus perfilhos para obtenção do palmito, o impacto da doença na produção é grande, pois reduz a longevidade dos plantios. Apesar de sua importância socioeconômica em várias regiões brasileiras, a pupunheira tem recebido pouca atenção fitopatológica.

A PBE é causada pelo oomiceto Phytophthora palmivora (Butler) Butler (18) e, no Brasil, este patógeno já foi relatado em São Paulo (16), Paraná (18), Pará (2), Pernambuco (26), Goiás (27), Bahia (24), Paraná (18) e Santa Catarina (23). No entanto, por ser uma doença de ocorrência recente no Brasil, há poucas informações sobre a sua etiologia, e os poucos registros, em sua maioria, são pontuais e sem descrição e identificação consistentes do agente causal. Além disso, não se sabe ainda se há envolvimento de mais de uma espécie de Phytophthora como é comum em outros hospedeiros cultivados no Brasil, tais como: o cacaueiro que é atacado por P. palmivora, $P$. capsici, $P$. citrophthora e $P$. heveae (11) e a seringueira por $P$. palmivora, $P$. citrophthora e $P$. palmivora $(21,22)$.

Com a expansão dos cultivos a PBE pode tornar-se um fator limitante à cultura da pupunheira. Há, portanto, necessidade de pesquisas para melhor compreender a sua etiologia. Assim, este trabalho objetivou caracterizar morfofisológica e molecularmente isolados de Phytophthora sp. oriundos de três regiões brasileiras de cultivo da pupunheira visando a sua identificação específica.

\section{MATERIAL E MÉTODOS}

\section{Origem dos isolados}

Os isolados de Phytophthora sp. foram obtidos de amostras de plantas de pupunheira com sintomas de PBE coletadas em três regiões produtoras de pupunheira dos estados do Paraná, Santa Catarina e São Paulo. Os isolamentos foram feitos a partir de fragmentos da porção interna do estipe, os quais foram submetidos a desinfestação superficial em álcool $70 \%$ por 30 segundos, hipoclorito de sódio $0,5 \%$ por 30 segundos, lavagem em água ultrapurificada e esterilizada e remoção do excesso de água em papel esterilizado. Os fragmentos foram depositados em placas de Petri contendo ágar-água a $2 \%$ suplementado com benomil (40 ppm), PCNB (100 ppm), ampicilina (80 ppm) e cloranfenicol (40 ppm). As placas de Petri foram incubadas a $24^{\circ} \mathrm{C}$, por seis dias, no escuro. Após este período, foram obtidas culturas com hifas cenocíticas, típicas de Phytophthora. As colônias de Phytophthora foram repicadas para placas de Petri contendo meio V8-ágar (200 mL de suco V8, $4 \mathrm{~g}$ de CaCO3, $18 \mathrm{~g}$ de ágar e $800 \mathrm{~mL}$ de água ultrapurificada). Foram obtidos 31 isolados de Phytophthora sp. mantidos em óleo mineral Nujol e Castellani na coleção da Embrapa Florestas, Colombo-PR, conforme segue: São Paulo - Cajati (SA15, SA16, SA17, SA18), Eldorado (SA8, SA13, SA14) e Registro (SA34, SA34-A, SA35, SA35-A, SA35-B); Paraná - Morretes (SP1, SA5) e Paranaguá (SA2, SA3, SA9, SA12, SA30, SA30-A, SA31, SA31-A, SA32, SA32-A); Santa Catarina - Garuva (SA33, SA33-A, Matatias), Joinville (SA11, SA19, SA20) e Massaranduba (SA10).

Caracterização morfológica dos isolados de Phytophthora sp.

Para avaliação das características culturais os isolados foram cultivados em meio V8-ágar a $24{ }^{\circ} \mathrm{C}$, por sete dias, no escuro. A avaliação da descrição do aspecto morfológico de cada colônia foi realizada conforme Erwin \& Ribeiro (7).

Para a avaliação da esporulação os isolados de Phytophthora sp. foram cultivados em placas de Petri com meio V8-ágar, sob luz contínua, em condições de laboratório, por sete dias. Após esse período foram retirados discos $(5 \mathrm{~mm})$ de meio de cultura com massa micelial esporulante e tocados em gotas de azul de metileno e lactoglicerol sobre lâminas de vidro, para o deslocamento e a coleta de esporângios. Posteriormente, sob microscópio de luz, observou-se a forma dos esporângios; determinou-se a largura e o comprimento do esporângio, a largura e a profundidade da papila e o comprimento do pedicelo. Para os clamidósporos determinou-se o diâmetro, a largura da parede da estrutura e sua disposição, terminal ou intercalar. De cada estrutura foram medidas 50 unidades para cada isolado de Phytophthora sp.

Para avaliar a ontogenia dos esporângios, discos $(5 \mathrm{~mm}$ de diâmetro) de micélio dos isolados de Phytophthora sp. crescidos em V8-ágar por sete dias, foram transferidos para placas de Petri contendo extrato de solo não-autoclavado ( $50 \mathrm{~g}$ de solo colocado em $1 \mathrm{~L}$ de água ultrapurificada e esterilizada). As placas foram mantidas no ambiente de laboratório, sob luz contínua, por 48 horas. Após esse período as placas foram observadas ao microscópio (objetiva 10X) quanto a ontogenia dos esporângios.

Para avaliação das estruturas sexuadas procedeu-se ao pareamento dos isolados de Phytophthora sp. com isolados padrões de Phytophthora frigida, grupos de compatibilidade A1 e A2, obtidos da coleção da Embrapa Florestas, Colombo-PR. Para isso um disco $(5 \mathrm{~mm}$ de diâmetro) de meio V8-ágar com micélio em crescimento ativo de cada isolado de Phytophthora sp. foi retirado e colocado em uma placa de Petri com meio V8-ágar. Do lado oposto, outro disco do mesmo diâmetro contendo micélio do isolado padrão foi colocado a uma distância de aproximadamente $3 \mathrm{~cm}$ entre eles. As placas de Petri foram envoltas em papel alumínio e acondicionadas em câmaras do tipo BOD a $24^{\circ} \mathrm{C}$, por seis dias, em escuro contínuo. A compatibilidade dos isolados foi avaliada pela presença ou não de oósporos e medidas 50 unidades por isolado.

Foi avaliado o crescimento micelial nas temperaturas $8,12,16,20$, $24,28,32$ e $36^{\circ} \mathrm{C}$. Para isso, discos ( $5 \mathrm{~mm}$ de diâmetro) de cultura em V8-agar com sete dias foram transferidos para o centro de placas de Petri contendo meio de cultura V8-ágar, as quais foram incubadas nas 
respectivas temperaturas, no escuro, por sete dias. Foram utilizados três repetições para cada isolado, em cada temperatura. As avaliações foram feitas no terceiro, quinto e sétimo dia após a instalação do experimento. As medições ocorreram em dois sentidos diametralmente opostos com o auxílio de um paquímetro digital. $\mathrm{O}$ diâmetro da colônia foi expresso pela média aritmética das duas medidas. Para determinar a temperatura ótima de crescimento dos isolados foi realizada a regressão polinomial com os dados no Excel $^{\circledR}$ e depois calculada a derivada da primeira da regressão.

Caracterização molecular dos isolados de Phytophthora sp.

O processo de extração de DNA foi realizado seguindo protocolo para extração de DNA de plantas do kit Wizard Genomic DNA Purification (Promega, Madison, EUA), seguindo as recomendações do fabricante. A análise do produto da extração do DNA foi realizada em gel de agarose $0,8 \%(0,40 \mathrm{~g}$ de agarose para $50 \mathrm{~mL}$ de tampão SB $0,5 \mathrm{x})$.

Foram amplificadas duas regiões ITS1 e ITS2 do DNA ribossomal (rDNA) e Cox1 e Cox2 do DNA mitocondrial (mtDNA). Para a amplificação das regiões ITS1 e ITS2, foram empregados os pares de primers ITS4 (5'-TCCTCCGCTTATTGATATGC-3') e ITS6 (5'-GAAGGTGAAGTCGTAACAAGG-3') (10). A reação de PCR foi executada com volume total de $15 \mu \mathrm{L}$, contendo $2 \mu \mathrm{L}$ do DNA genômico, $6,7 \mu \mathrm{L}$ de água ultrapurificada, $0,45 \mu \mathrm{L}$ de $\mathrm{MgCl} 2(50 \mathrm{mM})$, $1,5 \mu \mathrm{L}$ de tampão de PCR (10x), 1,2 $\mu \mathrm{L}$ de dNTP's $(2,5 \mathrm{mM}), 1,5 \mu \mathrm{L}$ de cada primer e $0,15 \mu \mathrm{L}$ da Taq DNA polimerase, e volume final de $15 \mu \mathrm{L}$. As amplificações foram efetuadas em termociclador Applied Biosystems, programada para 35 ciclos, cada um constituído pela seguinte sequência: $94{ }^{\circ} \mathrm{C}$ por $3 \mathrm{~min}, 94^{\circ} \mathrm{C}$ por $1 \mathrm{~min}, 55^{\circ} \mathrm{C}$ por 1 min, foi feita uma etapa de extensão final de $72{ }^{\circ} \mathrm{C}$ por 1 min e, por último, a temperatura foi reduzida para $4{ }^{\circ} \mathrm{C}$.

Para amplificação das regiões $\operatorname{Cox} 1$ e $\operatorname{Cox} 2$ a reação de PCR foi executada com volume total de $15 \mu \mathrm{L}$, contendo $2 \mu \mathrm{L}$ do DNA genômico, 5,65 $\mu \mathrm{L}$ de água ultrapurificada, $0,9 \mu \mathrm{L}$ de $\operatorname{MgCl} 2(3 \mathrm{mM})$, 1,5 $\mu \mathrm{L}$ de tampão de PCR (10x), 1,2 $\mu \mathrm{L}$ de dNTP's $(2,5 \mathrm{mM}), 1,5 \mu \mathrm{L}$ de cada primer e $0,75 \mu \mathrm{L}$ da Taq DNA polimerase, e volume final de $15 \mu \mathrm{L}$. As amplificações foram efetuadas em termociclador Applied Biosystems, programada para 40 ciclos: $95^{\circ} \mathrm{C}$ por $3 \mathrm{~min}, 95^{\circ} \mathrm{C}$ por $1 \mathrm{~min}, 65,5^{\circ} \mathrm{C}$ por $1 \mathrm{~min}$ e $72^{\circ} \mathrm{C}$ por $1 \mathrm{~min}$ de extensão final, e a temperatura reduzida para $4^{\circ} \mathrm{C}$.

Após a amplificação as amostras foram aplicadas em gel de agarose $(2 \% \mathrm{v} / \mathrm{v}), \operatorname{com} 3 \mu \mathrm{L}$ de produto da PCR amplificado juntamente à $3 \mu \mathrm{L}$ de tampão de corrida (loading buffer) procedendo-se a corrida a $100 \mathrm{~V}$. Os fragmentos amplificados foram visualizados em um transluminador. As reações de sequenciamento consistiram de $3 \mu \mathrm{L}$ do produto de PCR purificado, 0,5 $\mu \mathrm{L}$ de Buffer; 0,5 $\mu \mathrm{L}$ de cada iniciador (primer); 0,5 $\mu \mathrm{L}$ do Big-Dye, completando-se para um volume final de $10 \mu \mathrm{L}$ com água ultra pura. As condições de amplificação utilizadas foram: 96 ${ }^{\circ} \mathrm{C}$ por $1 \mathrm{~min}$, e por 35 ciclos a $96{ }^{\circ} \mathrm{C}$ por $10 \mathrm{~s}, 50^{\circ} \mathrm{C}$ por $5 \mathrm{~s} \mathrm{e} 60^{\circ} \mathrm{C}$ por $4 \mathrm{~min}$. As amostras foram sequenciadas em sequenciador Applied Biosystems.

As sequências de rDNA e mtDNA dos isolados foram comparados com sequências de Phytophthora disponíveis no Phytophthora-ID (http://phytophthora-id.org/). Os resultados foram interpretados encontrando semelhanças entre as sequências em análise e as disponíveis no banco de dados para Phytophthora.

Teste de patogenicidade dos isolados de Phytophthora sp. - Para a obtenção da suspensão de zoósporos as culturas de Phytophthora sp. foram crescidas em meio V8-ágar e incubadas sob luz contínua durante sete dias. Ao final deste período $10 \mathrm{~mL}$ de água ultrapurificada e esterilizada foi adicionado a cada placa de Petri, sendo estas colocadas em geladeira por trinta minutos. Em seguida as culturas de Phytophthora sp. foram deixadas sobre a bancada em condições de ambiente de laboratório por mais trinta minutos para que houvesse a liberação dos zoósporos. A suspensão obtida em cada placa foi vertida em um copo de Béquer, separando uma alíquota para a determinação da concentração de zoósporos em câmara de Neubauer.

A inoculação consistiu na injeção de uma alíquota de $0,1 \mathrm{~mL}$ da suspensão de $2,2 \times 10^{6}$ zoósporos.mL-1 de Phytophthora sp., com seringa descartável, em uma incisão feita, previamente, na base do estipe das mudas de pupunheira (8). A testemunha consistiu em injetar uma alíquota de $0,1 \mathrm{~mL}$ de água ultrapurificada e esterilizada. A avaliação foi realizada observando os sintomas da doença.

\section{RESULTADOS}

Os 31 isolados de Phytophthora sp. apresentaram três padrões de colônia em V8-ágar, conforme segue: estrelado (3,3\%), ligeiramente estrelado $(93,5 \%)$ e cotonoso $(3,2 \%)$ (Figura 1E). O micélio apresentou-se hialino com hifas cenocíticas. Os isolados produziram abundantemente esporângios em meio de V8-ágar. Os esporângios eram caducos e papilados, predominantemente elipsoides, apresentando outras formas como ovoides, globosos, limoniformes, obturbinados e formas distorcidas (Figura 1). As dimensões dos esporângios variaram de $21,1-84,8 \mu \mathrm{m}$ no comprimento (C) e de 17,4 - 41,7 $\mu \mathrm{m}$ na largura (L), com média de 41,0 x 26,1 $\mu \mathrm{m}$. A relação $\mathrm{C} / \mathrm{L}$ variou de 1,3 a 1,9 . As medidas da papila, profundidade $(\mathrm{P}) \mathrm{e}$ largura (L), variaram de $11,4 \times 11,2 \mu \mathrm{m}$ até $0,5 \times 0,9 \mu \mathrm{m}$ com média de $4,2 \times 5,1 \mu \mathrm{m}$ (Tabela 1 ).

O tamanho do pedicelo variou de 0,4 a $6,6 \mu \mathrm{m}$ com média de 1,5 $\mu \mathrm{m}$. Todos os isolados de Phytophthora sp. formaram clamidósporos, apresentando-se como globosos, terminais ou intercalares com diâmetro variando de 20,0 - 53,6 $\mu \mathrm{m}$ com uma média de 23,3 $\mu \mathrm{m}$ e espessura de parede variando de 0,3 - 4,4 $\mu \mathrm{m}$ com uma média de 1,59 $\mu \mathrm{m}$ (Figura 1). Em extrato de solo, a produção de esporângios foi abundante e observou-se a presença de esporângios papilados, que apresentaram um arranjo simpodial (Figura 1A).

Os isolados de Phytophthora sp. não cresceram nas temperaturas de $8^{\circ} \mathrm{C}$ e $36^{\circ} \mathrm{C}$ e a temperatura ótima variou de $23,6^{\circ} \mathrm{C}$ a $23,9^{\circ} \mathrm{C}$.

Os fragmentos das regiões ITS1 e ITS2 do rDNA e os das regiões Cox 1 e Cox 2 do mtDNA amplificados dos isolados de Phytophthora sp. de pupunheira apresentaram 862 a 941 e 450 a 500 pares de bases, respectivamente. A comparação das sequências das regiões ITS e COX dos isolados com o banco de dados disponível no Phytophthora-ID revelou maior similaridade dos isolados com a espécie $P$. palmivora (Tabela 2), sendo que a similaridade dos isolados para a região ITS foi de 93 à 100\% e para a região Cox foi de 92 à 100\%.

No sétimo dia após a inoculação (7DAI), observou-se, nas plantas inoculadas, que $96 \%$ das mudas apresentavam sintomas caracterizados pelo amarelecimento da primeira folha aberta. Aos 14DAI, as mudas apresentaram sintomas de murcha e amarelecimento na folha bandeira (folha não aberta) e nas demais folhas e, aos 21DAI, 67\% das mudas inoculadas com P. palmivora estavam mortas. As plantas do tratamento testemunha não apresentaram sintomas. O patógeno foi reisolado a partir das amostras das plantas doentes, completando os postulados de Koch. Os 31 isolados de Phytophthora sp. foram patogênicos à pupunheira. 
Tabela 1. Dimensões das estruturas assexuadas e sexuadas dos isolados de Phytophthora sp. de pupunheira.

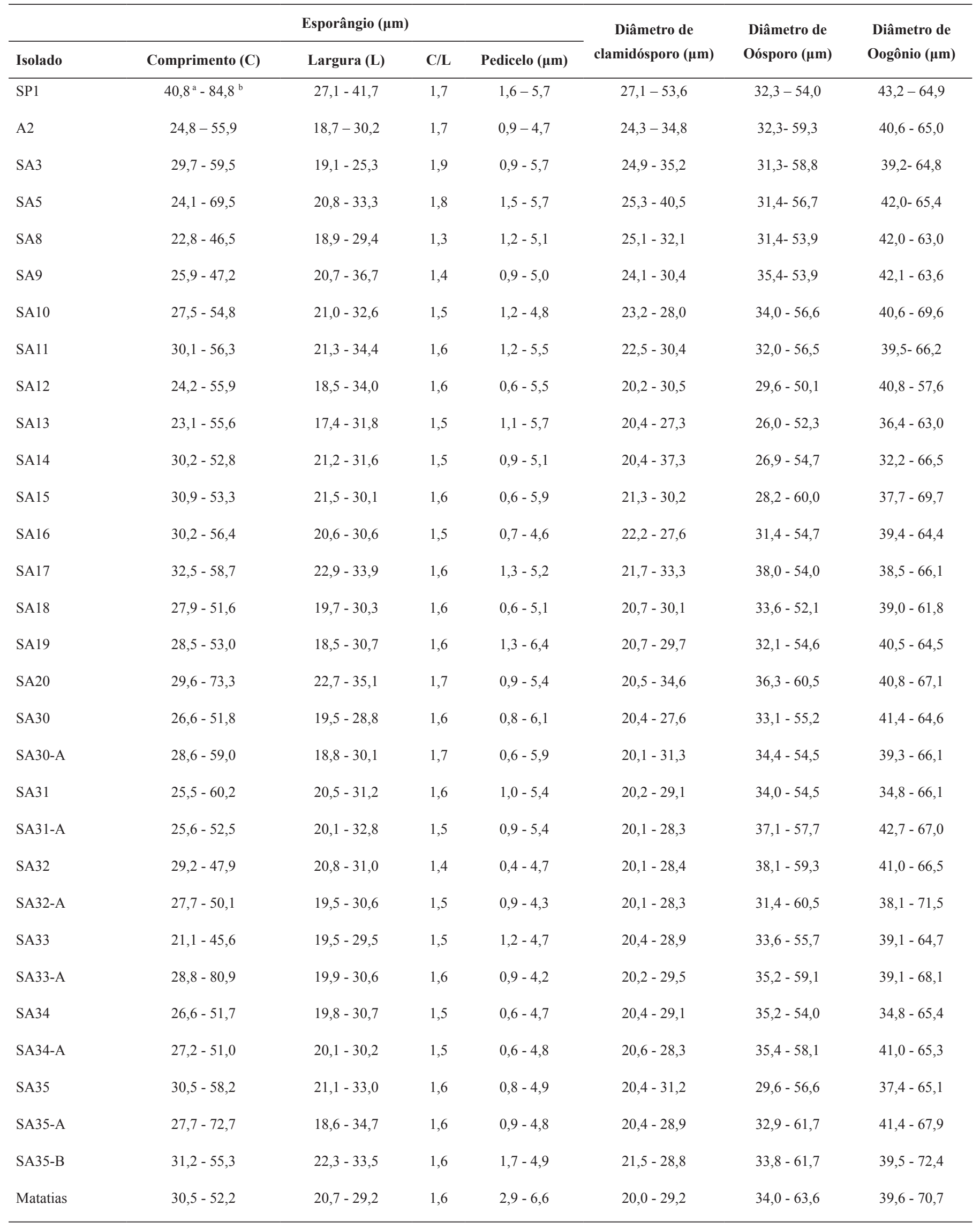

${ }^{a}$ Limite inferior; ${ }^{b}$ Limite superior 


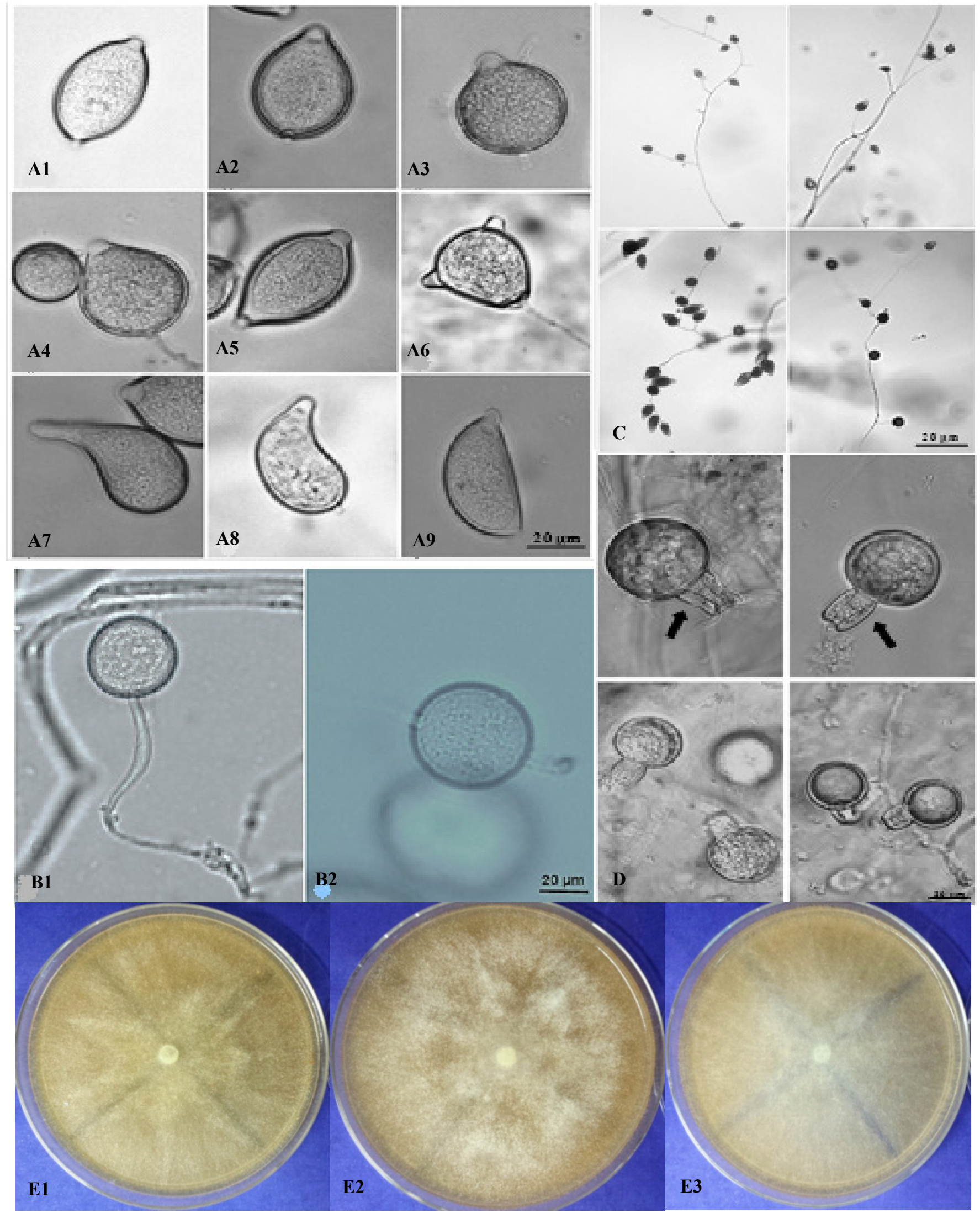

Figura 1. Morfologia de Phytophthora palmivora. Esporângios elipsoide (A1), ovoide (A2), globoso (A3), obturbinado (A4) e presença de um clamidósporo, limoniforme (A5), bipapilado (A6) e formas distorcidas (A7, A8 e A9); Clamidósporos terminal (B1) e intercalar (B2); Disposição simpodial dos esporângios nos esporangióforos (C); Ooósporos com anterídio anfígeno (D) (setas); e Morfologia das culturas em meio V8-ágar, a $24^{\circ} \mathrm{C}$, aos sete dias de cultivo: estrelada (E1), ligeiramente estrelada (E2) e cotonosa (E3). 
Tabela 2. Similaridade de isolados de Phytophthora palmivora de pupunheira, mediante comparação de sequências de DNA dos genes ITS e Cox do banco de dados Phytophthora-ID.

ITS Cox

\begin{tabular}{|c|c|c|c|c|c|}
\hline Isolado & Espécie & $\begin{array}{l}\text { Identidade em relação } \\
(\%) \text { à referência }\end{array}$ & $\begin{array}{c}\text { Referência no } \\
\text { Phytophthora-ID }\end{array}$ & $\begin{array}{l}\text { Identidade em relação } \\
(\%) \text { à referência }\end{array}$ & $\begin{array}{c}\text { Referência no } \\
\text { Phytophthora-ID }\end{array}$ \\
\hline $\mathrm{SA} 2$ & P. palmivora & 99 & AF266780 & 99 & P10769 \\
\hline SA3 & P. palmivora & 99 & AF266780 & 100 & P10769 \\
\hline SA5 & P. palmivora & 99 & AF266780 & 97 & P10769 \\
\hline SA8 & P. palmivora & 96 & AF266780 & 99 & P10769 \\
\hline SA10 & P. palmivora & 94 & AF266780 & 99 & P10769 \\
\hline SA11 & P. palmivora & 92 & AF266780 & 98 & P10769 \\
\hline SA12 & P. palmivora & 99 & AF266780 & 95 & P10769 \\
\hline SA13 & P. palmivora & 98 & AF266780 & 94 & P10769 \\
\hline SA18 & P. palmivora & 99 & AF266780 & 99 & P10769 \\
\hline SA20 & P. palmivora & 99 & AF266780 & 95 & P10769 \\
\hline SA30 & P. palmivora & 99 & AF266780 & 97 & P10769 \\
\hline SA30-A & P. palmivora & 99 & AF266780 & 99 & P10769 \\
\hline SA31-A & P. palmivora & 99 & AF266780 & 99 & P10769 \\
\hline SA32 & P. palmivora & 100 & AF266780 & 98 & P10769 \\
\hline SA32-A & P. palmivora & 99 & AF266780 & 96 & P10769 \\
\hline SA33 & P. palmivora & 99 & AF266780 & 99 & P10769 \\
\hline
\end{tabular}

\section{DISCUSSÃO}

Neste estudo foram caracterizados 31 isolados de Phytophthora sp. oriundos de plantas com sintomas da PBE de três regiões brasileiras produtoras de pupunheira no Brasil. Phytophthora sp. foi consistentemente isolado das amostras de plantas sintomáticas de pupunheira jovens e adultas e todos os isolados foram patogênicos à pupunheira. Os isolados de Phytophthora sp. produziram em meio V8ágar esporângios caducos, com pedicelos curtos, papilados, presença de clamidósporos, culturas heterotálicas e anterídios anfígenos. As caraterísticas morfológicas dos isolados assemelham-se a Phytophthora palmivora (Butler) Butler (7, 9, 25). A identificação foi confirmada através da análise dos fragmentos das regiões ITS1 e ITS2 do rDNA e Cox 1 e Cox2 de mtDNA. Phytophthora palmivora encontra-se no grupo II (29) e clado 4 (4).

As características morfológicas assexuadas (esporângio e clamidósporo) e sexuadas (oogônio, anterídio e oósporo) têm sido usadas para identificar as espécies de Phytophthora $(7,9,25)$. No presente estudo os isolados de $P$. palmivora produziram esporângios caducos e papilados, relação $\mathrm{C} / \mathrm{L}$ variando de 1,3 a 1,9 , com pedicelo pequeno $(<6,6 \mu \mathrm{m})$, em acordo com o que outros autores já reportaram para esta espécie em pupunheira $(16,18)$ e em outros hospedeiros, como figo (Ficus carica L.) (20), mamoeiro (Carica papaya L.) (5), cacaueiro (Theobroma cacao) (6) e seringueira (Hevea brasiliensis) (21). Santos et al. (18) verificaram em isolados de P. palmivora de pupunheira dimensões parecidas para os esporângios $(30,7 \times 46,4 \mu \mathrm{m})$, além de outras características como papilas proeminentes $(6,4 \times 7,9$ $\mu \mathrm{m})$ e ontogenia simpodial. Em outros hospedeiros, como damasco (Prunus armeniaca L.), Türkölmez et al. (28) também reportaram que os isolados de $P$. palmivora apresentaram ontogenia simpodial e dimensões de esporângios $(36,0$ x $42,5 \mu \mathrm{m})$ e pedicelo $(<3 \mu \mathrm{m})$ que se assemelham às deste trabalho. Resultados parecidos para características esporangiais de $P$. palmivora também foram observadas por Carnaúba et al. (6) em mamoeiro e Machado et al. (12) em abacateiro. 
Os clamidósporos são produzidos por mais de 32 espécies de Phytophthora (7), sendo que algumas espécies produzem clamidósporos com maior frequência que outras. No presente estudo todos os isolados de P. palmivora produziram clamidósporos. Clamidósporos com dimensões similares às deste trabalho também foram relatadas por outros autores para trabalhos com P. palmivora em pupunheira (18) e em damasco (28). De acordo com Stamps et al. (25), as características morfológicas dos clamidósporos podem ser usadas como caráter taxonômico para diferenciar algumas espécies de Phytophthora, enquanto que Erwin \& Ribeiro (7) afirmam que a morfologia dos clamidósporos não varia muito entre as espécies de Phytophthora, sendo a importância desse caráter na taxonomia, na maioria das vezes, limitada à sua presença ou ausência.

Outro aspecto importante para classificação taxonômica de Phytophthora é em relação à sua natureza homotálica ou heterotálica, bem como a posição do anterídio. No presente estudo todos os isolados de P. palmivora foram heterotálicos do tipo A1, produzindo oósporos globosos e apleróticos e anterídios anfígenos. Santos et al. (18) também observaram a presença de anterídios anfígenos em culturas de $P$. palmivora de pupunheira.

Erwin \& Ribeiro (7) relatam que a temperatura é um fator importante na caracterização de Phytophthora, uma vez que cada espécie possui uma temperatura máxima de crescimento. Dessa forma, esta característica pode auxiliar na separação de espécies morfologicamente semelhantes. Em estudos realizados por Santos et al. (18) e Pizzinatto et al. (16) os isolados de P. palmivora de pupunheira não apresentaram nenhum crescimento a $35{ }^{\circ} \mathrm{C}$. Neste estudo $P$. palmivora também não cresceu $35^{\circ} \mathrm{C}$.

Os 31 isolados de $P$. palmivora foram patogênicos à pupunheira. A patogenicidade de $P$. palmivora à pupunheira também foi demonstrada por Pizzinatto et al. (16), Alves et al. (1) e Santos et al. (18). Como demonstrado neste trabalho, até o momento apenas $P$. palmivora foi encontrada atacando a pupunheira. Phytophthora palmivora é uma espécie com ampla distribuição no mundo e com elevada gama de hospedeiros (7) e, no Brasil, P. palmivora é patogênica a 13 espécies botânicas pertencentes a 10 famílias (17). Na família Arecaceae $P$. palmivora ataca a pupunheira (16) e o coqueiro (Cocos nucifera) (3).

A caracterização molecular dos isolados de pupunheira com base no sequenciamento das regiões ITS1 e ITS2, do DNA ribossomal e Cox1 e Cox2, do DNA mitocondrial, demonstrou similaridade com sequencias de isolados da espécie $P$. palmivora depositados no banco de dados Phytophthora-ID. As regiões, ITS do DNA ribossomal e Cox do DNA mitocondrial, têm sido usadas para identificar $P$. palmivora e separá-la de espécies estreitamente relacionadas $(9,13,20,28)$.

Este trabalho confirma o envolvimento de $P$. palmivora como agente causal da PBE da pupunheira no Brasil, corroborando com relatos anteriores feitos por Benchimol et al. (2), Pizzinatto et al. (16), Santos et al. (18) e Santos et al. (23).

\section{REFERÊNCIAS}

1. Alves, S.A.R.; Santos, A.F.; Tessmann, D.J.; Vida, J.B. Patogenicidade de isolados de Fusarium spp. e Phytophthora palmivora associados com a podridão do estipe da pupunheira no Paraná. Boletim de Pesquisa Florestal, Colombo, n.52, p.133-140, 2006.

2. Benchimol, R.L.; Albuquerque, F.C.; Muller, C.H. Podridão da base do estipe da pupunheira causada por Phytophthora palmivora. Fitopatologia Brasileira, Brasília, v.32, n.2, p.181, 1998.

3. Bezerra, J.L.; Luz, E.D.M.N. Podridão do olho e queda dos frutos do coqueiro. In: Luz, E.D.M.N.; Santos, A.F. dos; Matsuoka, K.; Bezerra,
J.L. Doenças causadas por Phytophthora no Brasil. Campinas: Livraria Rural, 2001. p.343-357.

4. Blair, J.E.; Coffey, M.D.; Park, S.Y.; Geiser, D.M.; Kang, S. A multi-locus phylogeny for Phytophthora utilizing markers derived from complete genome sequences. Fungal Genetics and Biology, v.45, p.266-277. 2008.

5. Carnaúba, J.P.; Sobral, M.F.; Furtado, D.C.; Silva, I.O.; Silva, K.M.; Amorim, E.P. Phytophthora palmivora, agente da podridão de raiz e fruto de mamoeiro no estado de Alagoas. Revista Brasileira de Fruticultura, Jaboticabal, v.28, n.1, p.134-135, 2006.

6. Cerqueira, A.O.; Luz, E.D.M.N.; Rocha, C.S.S. Caracterização morfológica e biométrica de alguns isolados de Phytophthora spp. da micoteca do Centro de Pesquisas do Cacau. Fitopatologia Brasileira, Brasília, DF, v.24, p.114-119, 1999.

7. Erwin, D.C.; Ribeiro, O.K. Phytophthora diseases worldwide. St. Paul: APS Press, 1996. 562 p.

8. Fuzitani, E.J.; Santos, A.F.; Moraes, W.S.; Damatto Junior, E.R.; Nomura, E.S. Eficiência de fosfitos no controle da podridão da base do estipe em mudas de pupunheira. Revista Brasileira de Fruticultura, Jaboticabal, v.35, n.4, p.1000-1006, 2013.

9. Gallegly, M.E.; Hong, C. Phytophthora: Identifying Species by Morphology and DNA Fingerprints. St. Paul: APS Press, 2008. 158p.

10. Lopes, H.V. Caracterização morfofisiológica e molecular de isolados de Phytophthora palmivora da pupunheira. 2016. 66p. Dissertação (Mestrado em Agronomia) - Universidade Federal do Paraná, Curitiba.

11. Luz, E.D.M.N.; Silva, S.D.V.M. Podridão-parda dos frutos, cancro e outras doenças causadas por Phytophthora no cacaueiro. In: Luz, E.D.M.N.; Santos, A.F.; Matsuoka, K.; Bezerra, J.L. Doenças causadas por Phytophthora no Brasil. Campinas: Livraria Rural, 2001. p.175-265.

12. Machado, M.; Peña-Marey, M.; Alvarez, A.; Díaz, A.; Zamora, V.; Coto, O. Variabilidad intraespecífica de cepas de Phytophthora palmivora Butler (Butler) aisladas de plantaciones de aguacatero (Persea americana Mill.) en Cuba. Revista de Protección Vegetal, San José de las Lajas, v.28, n.3, p.178-184, 2013

13. Martin, F.N.; Abad, Z.G.; Balci, Y.; Ivors, K. Identification and detection of Phytophthora: reviewing our progress, identifying our needs. Plant Disease, St. Paul, v.96, n.8, p.1080-1103, 2012.

14. Neves, E.J.M.; Santos, A.F. dos. Produção de pupunheira (Bactris gasipaes) para palmito sob diferentes espaçamentos, no litoral do estado do Paraná. Pesquisa Florestal Brasileira, Colombo, n.56, p.87-95, 2008.

15. Penteado Júnior J.F.; Santos, A.F.; Neves, E.J.M. Aspectos do agronegócio do palmito de pupunha no Brasil. Documentos Embrapa Florestas, Colombo, v.275, p.1-21, 2014.

16. Pizzinatto, M.A.; Bovi, M.L.A.; Feichtenberg, E.; Spiering, S.H. Ocorrência da podridão do estipe em pupunheira, causada por Phytophthora palmivora, no estado de São Paulo. Summa Phytopathologica, São Paulo, v.28, n.4, p.363-365, 2002

17. Santos, A.F. dos; Luz, E.D.M.N.; Reis, A. Phytophthora spp.: distribuição e associação com espécies florestais. In: Congresso Brasileiro de Fitopatologia, 47.; Simpósio Brasileiro de Mofo Branco, 2014, Londrina. Desafios futuros: anais. Londrina: SBF, 2014.

18. Santos, A.F. dos; Luz, E.D.M.N.; Finato, P.D; Tessmann, D.J.; Vida, J.B. Primeiro relato da podridão da base do estipe da pupunheira causado por Phytophthora palmivora, no Estado do Paraná. Fitopatologia Brasileira, Brasília, v.29, p.6, 2004.

19. Santos, A.F. dos; Tessmann, D.J.; Vida, J.B. Doenças das Palmeiras para palmito. In: Santos, A.F.; Corrêa Jr, C.; Neves, E.J.M. Palmeiras para produção de palmito Juçara, Pupunheira e Palmeira Real. Colombo: Embrapa Florestas, 2008. p.106-120.

20. Santos, A.F. dos; Santos, F.; Mezzomo, R.; Tessmann, D.J.; May de Mio, L.L. First report of fruit rot caused by Phytophthora palmivora on fig in Brazil. Plant Disease, St. Paul, v.101, n.7, p.1331, 2017.

21. Santos, A.F. dos; Matsuoka, K.; Alfenas, A.C.; Maffia, L.A. Identificação de espécies de Phytophthora patogênicas à seringueira. Fitopatologia Brasileira, Brasília, DF, v.20, n.2, p.151-159, 1995.

22. Santos, A.F. dos; Luz, E.D.M.N.; Auer, C.G. Phytophthora em espécies florestais. In: Núcleo de Estudos em Fitopatologia. (Org.). Patologia florestal: desafios e perspectivas. 1.ed. São Carlos: Suprema Gráfica e Editora, 2013. p.157-167.

23. Santos, A.F. dos; Tessmann, D.J.; Vida, J.B. Ocorrência da podridão do estipe (Phytophthora palmivora) da pupunheira em Santa Catarina. Fitopatologia Brasileira, Brasília, DF, v.32, p.308, 2007. Suplemento. 
24. Santos, A.F. dos.; Luz, E.D.M.N. Doenças emergentes causadas por Phytophthora no Brasil. Fitopatologia Brasileira, Brasília, DF, v.32, p.41-43, 2007.

25. Stamps, D.J. Waterhouse, G.M.; Newhook, F.J.; Hall, G.S. Revised tabular key to the species of Phytophthora. Mycological Papers, Kew, Surrey, n.162, p.1-28, 1990.

26. Tavares, S.C.C.H.; Nascimento, A.R.; Lima, J.A.S.; Menezes, W.A.; Cruz, S.C. Doenças da pupunha em áreas irrigadas na região do submédio São Francisco. Fitopatologia Brasileira, Brasília, v.23, p.286, 1998. Suplemento.
27.Tomita, C.K.; Lima, M.A.; Uesugi, C.H. Levantamento de perdas econômicas causadas por Phytophthora palmivora em cultura de pupunha (Bactris gasipaes Kunth.) na região geo-econômica de Padre-Bernardo-GO. Fitopatologia Brasileira, v.31, p.296, 2006. Suplemento.

28.Türkölmez, S.; Ciftçi, O.; Canihoș, E.; Serçe, C.U.; Derviș, S. Phytophthora Crown and Root Rot of Apricot Caused by Phytophthora palmivora in Turkey. Journal of Phytopathology, Berlin, v.163, n.6, p.498-502, 2015

29. Waterhouse, G.M. Key to the species of Phytophthora de Bary. Kew: Commonweath Mycological Institute, 1963. (Mycological Papers, ' 92). 